\author{
Paweł Król \\ AGH University of Science and Technology \\ al. Mickiewicza 30, 30-059 Kraków, pawel.krol@agh.edu.pl \\ Goran Krajačić \\ University of Zagreb \\ Trg Republike Hrvatske 14, 10000 Zagreb, goran.krajacic@fsb.hr
}

\title{
ENERGY ANALYSIS OF MUNICIPAL WASTE IN DUBROVNIK
}

\begin{abstract}
In each touristic city waste management system has to overcome the impact of visitors. Dubrovnik, famous as popular touristic destination, particularly notices tourists visiting city. Therefore potential impact of waste management in touristic cities, such as Dubrovnik, is presented. The paper includes estimation of yearly waste production by inhabitants and tourists visiting those city. Waste digestion is a method for biogas production. On the basis of the preceding estimation combined-cycle installation generating heat and electricity is proposed. The model combines Brayton cycle with low temperature Kalina model based on Rankine cycle. Literature analysis presents state of the art in this field. The simulation is prepared in Cycle-Tempo. Numerical analyses lead to technical issues, which have to be taken into consideration during waste utilization with such installation. Thus benefits and threats are discussed. The presented analysis assesses the maximal electric gain, which subsequently should consider waste preparation and purification.
\end{abstract}

\section{Key words}

Waste Management, Kalina Cycle, Brayton cycle, Anaerobic Digestion, Biogas, Asimptote Cycle-Tempo.

\section{Introduction}

City of Dubrovnik with ambient surrounding villages is separated from mainland Croatia by Bosna and Hercegovina to which belongs 12 miles of coastline. Thus such area surrounded within international boundaries is independent region. It impacts both politics and economy. The miscellaneous history and Mediterranean localization are appreciated by tourists, thus tourism in Dubrovnik is core of the economy in the city. Dubrovnik with 43731 residents is a relatively small city. Nevertheless, total number of tourists visited Dubrovnik in 2015 is estimated around 889700 [1] and around 1 million visitors visits with cruise ships, which berth in port for few hours [2].

Naturally municipal management in the region is also separated from mainland. Influence of waste management in the city is studied. The two waste producers - tourists and inhabitants are taken into consideration. The concentration of touristic demand is noticeable and impact of mass tourism to the environmental infrastructure in this city is burdensome. The paper focuses on the utilization of municipal waste produced in Dubrovnik by anaerobic digestion and biogas combustion in low temperature installation. Simulation prepared in Cycle-Tempo allows to assess the applicability of such bio-gas combustion in cities like Dubrovnik.

\section{Energy industry in Croatia and Dubrovnik}

Croatia has considerable green energy production - due to noticeable potential for new renewables country reached balanced electricity production. According to data prepared by Eurostat [3] total Croatian electricity production in 2014 exceeds 4353 ktoe (kilo tons of oil equivalent). The Fig. 1 juxtaposes the changes in electricity production in Croatia. Taking into consideration year 2014 the proportions of primary production are following: crude oil 14\%, natural gas 33\%, renewables 52\%. The share of electricity produced of non-renewable waste is negligible in the country's electricity mix. 


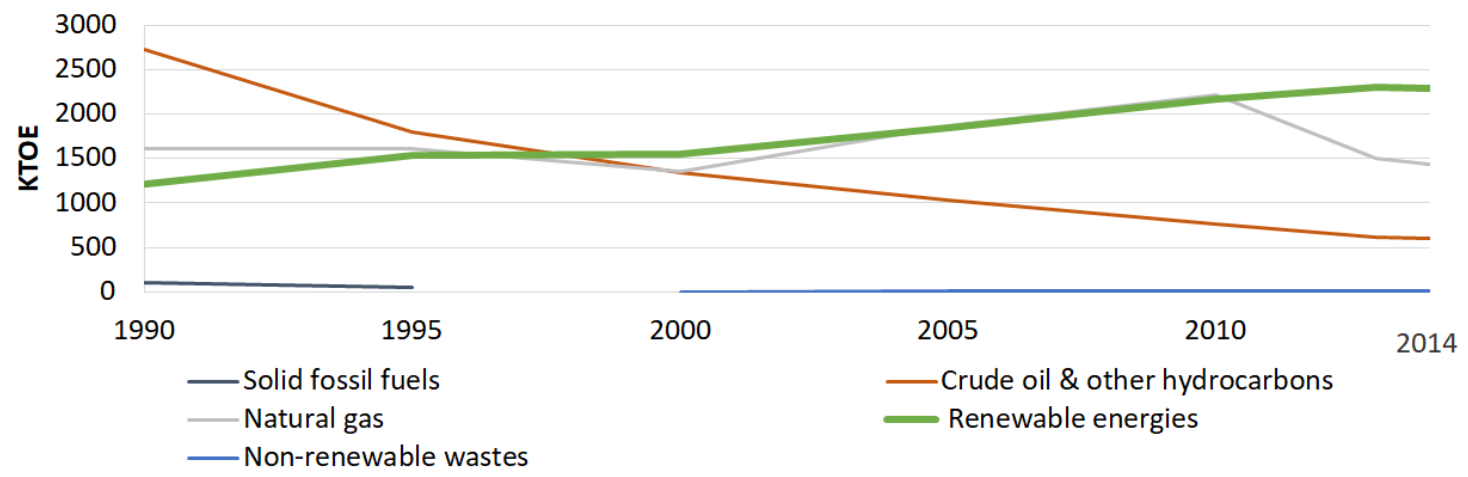

Fig. 1. Primary production of energy resources in Croatia within last 3 decades Source: [3]

Dubrovnik, similarly to whole Croatia, has high potential for renewables - hydro, wind and solar. Therefore the most significant electricity producers in Dubrovnik area are green installations. Hydroelectric power plant is located on the coast in Plat, $15 \mathrm{~km}$ southeast of Dubrovnik and crosses two countries - Croatia and Bosnia and Herzegovina. Power plant is supplied by Bileća lake. Water flows through two $282 \mathrm{~m}$ long underground pipelines. Two aggregates with $126 \mathrm{MW}$ of installed capacity each are in the underground engine chamber [4]. There is also small hydro power plant Zavrelje $5 \mathrm{~km}$ from Dubrovnik with installed capacity of $2 \mathrm{MW}$. Hydropower is flexible, but also predictable and reliable. That makes it possible for hydropower to be the regulator that fills the gaps when other renewables can't produce. On the opposite side is wind power, the unstable and unpredictable power source. Sea coast of Dubrovnik has suitable weather conditions for wind turbines. One wind farm is located close to city Slano northwest from city of Dubrovnik. Plant consists of twelve turbines, each $85 \mathrm{~m}$ high. Diameter of blades is $103 \mathrm{~m}$. Each turbine has power of $2.85 \mathrm{MW}$, total 34.2 MW power wind turbines [5]. Krajacic et al. [6] observed that in region of Dubrovnik positive correlation between green production and electricity demand. When production of wind and solar electricity is lower the missing energy is supplied with conventional generation. Municipal waste is potential source of biogas, which is another way of green energy production. In this paper authors propose biofuel production that combustion will give potentially more green electricity in Dubrovnik region.

\section{Waste in Croatia and Dubrovnik}

Potentially different waste products could be treated as energy source in waste management system. Two waste sources are considered - solid waste and wastewater. Solid waste management is important issue in the Croatian environment. According to Schneider et al. [7] $3.7 \mathrm{Mt}$ of waste was produced in 2007 in Croatia. Waste is produced in $52 \%$ by municipal utilities and in $48 \%$ by industry. Omitting segregated waste, production of mixed municipal waste is $393 \mathrm{~kg}$ per capita. Unfortunately, the majority of waste is landfilled. Wastewater treatment, during which waste sludge is obtained, is second potential waste source. According to Serdar et al. [8] it is estimated that only about $43 \%$ of Croatian population is connected to sewage installation. During standard waste-water treatment process natural sludge is deposited in disposal sites. This solution causes major risks, thus partial industrial utilization is proposed. The capacity of sludge is estimated to 250000 tons per year [8].

According to David Styles [9] tourists may generate up to twice as much solid waste per capita as local resident. In report presented by Kožić [10] it is estimated that Croatian tourism participates with share of $3.8 \%$ in total quantity of waste (tourists produced 63371 tons of solid waste in 2012) and the share of tourism in water consumption of Croatia ranges from $4 \%$ to $5 \%$ of total water supply.

The intensive tourism strongly influences the waste management sector in the Dubrovnik region too. Gruber et al. [11] described the waste management in touristic cities on the basis of survey among waste workers. According to the research, the impact of tourism in the city is especially noticeable. Fig. 2 compares the city with other remarkable touristic regions. The result is justified - tourism in such a small city is significantly visible in waste sector. 


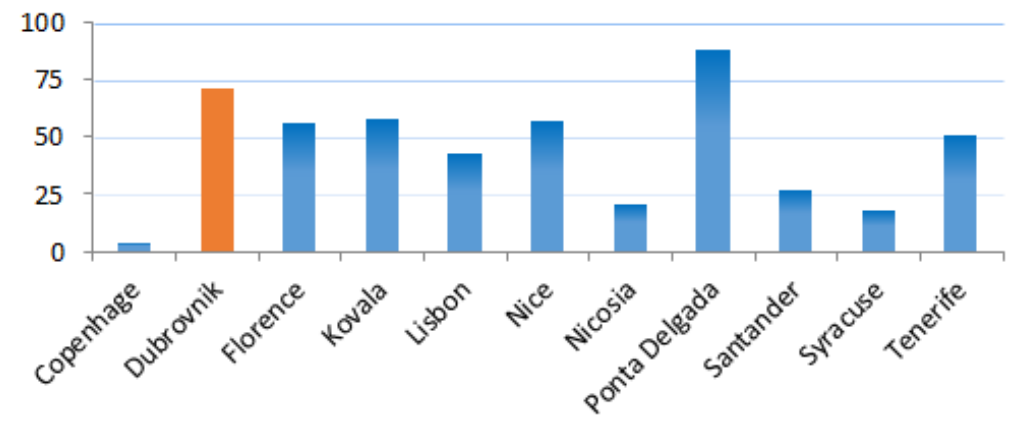

Fig. 2. Waste workers agreeing that tourism influences waste management Source: [11]

According to data proposed by Nikola Matak [12] in 2015 tourists produced 2862 tons of solid waste yearly, total disposed solid waste in city of Dubrovnik is 19035 tons. Thus around $15 \%$ of waste is produced by tourist in Dubrovnik region. It is estimated around $2875836 \mathrm{~m}^{3} /$ year of wastewater is produced in the city (Table 1).

Table 1. Waste production in city of Dubrovnik

\begin{tabular}{|l|l|}
\hline Waste source & Total \\
\hline Solid waste [tones/year] & 19035 \\
\hline Wastewater [m³/year] & 2875836 \\
\hline
\end{tabular}

Source: [12]

\section{Waste utilization to produce electricity}

Waste such as rubbish and wastewater could be treated as natural energy source. Proper storage conditions allow to produce biogas, that while being burned releases heat, which is utilized to generate energy [13]. The schematic of process is presented below (Fig.3).

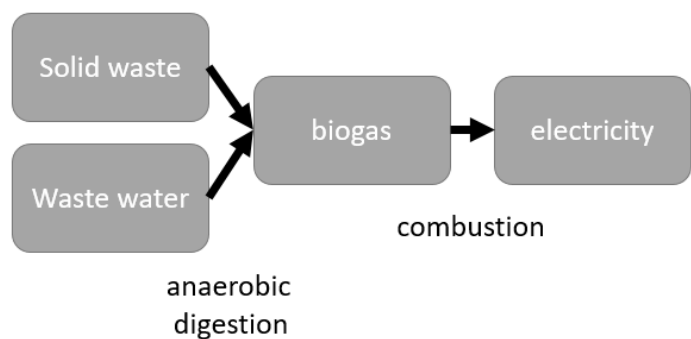

Fig. 3. Schematic of waste utilization be electricity production Source: [11]

Anaerobic digestion is primary method of utilization products such as plant remains, agricultural products or organic waste. It is natural processes by which microorganisms break down biodegradable material in the absence of oxygen - the amount of organic matter is reduced by extraction of gases. The process intensifies at elevated temperatures, thus external heat source is advantageous. The product of anaerobic digestion is biogas, which in up to $65 \%$ consists of methane and other non-flammable ingredients (carbon dioxide, water).

The biogas potential of solid waste depends on the amount of volatile solid. During anaerobic digestion around $0.42 \mathrm{~m}^{3}$ of biogas is obtained by processing $1 \mathrm{~kg}$ of biodegradable solid [14]. When the content of biodegradable ingredients in waste is $50 \%$, the yield of biogas is reduced to $0.21 \mathrm{~m}^{3}$ per $\mathrm{kg}$. Each $1 \mathrm{~m}^{3}$ of sewage contains around $0.5 \mathrm{~kg}$ of sludge [8]. Digestion of $1 \mathrm{~kg}$ of sewage sludge produces approximately $0.7 \mathrm{~m}^{3}$ of biogas [15]. Biogas extracted during anaerobic digestion of both solid waste and sewage sludge can be used as partial or complete fossil fuel for internal combustion engines and as such, is considered as potential source a renewable energy source. 
Combustion is conducted in reciprocating engines or turbines. Thermal energy changes to mechanical power which next is transferred to generator [16]. Turbines have more significant overall efficiency with high output of heat. In reciprocating engines higher share of total production is transformed into electricity.

The potential of anaerobic digestion to produce biogas is presented by Houdková [17] - authors present biogas production in laboratory and next comment potential of biogas utilization and in biogas production for vehicles. Matuszewska et al. [18] evaluated the biological methane potential of various feedstock for the production of biogas to supply engines in agricultural tractors. Otherwise, biogas can feed generators producing electricity in stationary local power plants. Some researchers focus on such waste management Željko et al. [7] propose energy recovery from waste by creation of waste management centers in regions of Croatia.

Waste digestate is utilized, incinerated or landfilled [15]. Pyrolysis of digestate is one of the utilization methods. Opatokun et al. [19] assessed the energy potential of food waste energy harvesting system. The authors concluded that transitional energy base products (biogas and bio-oil) are generated through the energy harvesting system of food waste, while energy rich solid fuels can be produced through pyrolysis at $500^{\circ} \mathrm{C}$. In [20] author propose approaches based on anaerobic digestion and pyrolysis of sewage management.

\section{Assumption of biogas production in city of Dubrovnik}

Residents in Dubrovnik produce sewage and solid waste, the utilization of which is a potential biogas source. Paragraph assesses energy production with biogas sources. The two biogas sources are taken into account: solid waste and wastewater (Table 1). Calculation below assesses the maximal biogas availability. In selected applications usage is reduced by the quality of biomaterial and other technics of management.

In the previous paragraph authors assumed that utilization of $1 \mathrm{~kg}$ of solid waste has the potential of $0.21 \mathrm{~m}^{3}$ of waste. Thus the potential biogas production from solid waste produced in Dubrovnik oscillates around $3807000 \mathrm{~m}^{3}$. At the same time $1 \mathrm{~m}^{3}$ of sewage might be transformed to $0.35 \mathrm{~m}^{3}$. Therefore potential yearly biogas production from waste water produced in the city oscillates around $1006000 \mathrm{~m}^{3}$.

Energy production correlates with the content of methane in biogas. It can range from $50-75 \%$ depending on the substrate and digestion process. Energy content of pure methane is about $9.97 \mathrm{kWh}$ [21]. It is assumed that $1 \mathrm{~m}^{3}$ of waste biogas has a content of $55 \%$ of methane that has an energy value of about 5.5kWh [22]. When lower heating value (LHV) of methane is $50.05 \mathrm{MJ} / \mathrm{kg}$ the LHV of biogas containing $55 \%$ of methane is around $27.52 \mathrm{MJ} / \mathrm{kg}[23]$.

Therefore, it can be assumed that yearly estimated total biogas potential is $4813000 \mathrm{~m}^{3}$. Assuming stable electricity supply biogas supply will vary around $0.15 \mathrm{~m}^{3} / \mathrm{s}$. Concluding that energy potential of $1 \mathrm{~m}^{3}$ biogas is around $5.5 \mathrm{kWh}$ the electricity yield from biogas in Dubrovnik region is around $24.27 \mathrm{GWh}$ per year. It corresponds to $2.77 \mathrm{MW}$ of absorbed energy in the combustion installation. Table 2 summarizes the calculations above.

Table 2. Estimation of energy obtained from waste in city of Dubrovnik

\begin{tabular}{|l|c|c|}
\hline & Solid Waste & Wastewater \\
\hline Yearly waste production & $19035[\mathrm{t}]$ & $2875836\left[\mathrm{~m}^{3}\right]$ \\
\hline Yearly utilization of biogas $\left[\mathrm{m}^{3}\right]$ & 3807000 & 1006000 \\
\hline Estimated biogas potential $\left[\mathrm{m}^{3}\right]$ & \multicolumn{2}{|c|}{$\mathbf{4 8 1 3 0 0 0}$} \\
\hline Potential energy yield [GWh] & \multicolumn{2}{|c|}{$\mathbf{2 4 . 2 7}$} \\
\hline Energy absorption [MW] & \multicolumn{2}{|c|}{$\mathbf{2 . 7 7}$} \\
\hline
\end{tabular}

Source: calculation on the basis of [12]

The values above present maximal energetic potential of municipal waste. Authors took all available waste into consideration omitting better techniques of management of selected materials. Another fact is that a certain share of electricity would be spent for the purposes of the preparatory phases, such as energy consuming waste preparation and ashes purification. Authors propose combined installation of biogas combustion - two cycles potentially increase the gain of electricity. 


\section{Biogas combustion and electricity generation}

Authors propose combined-cycle electricity generation. Firstly, electricity is produced during combustion of biogas in thermodynamic Brayton cycle. In compressor air is compressed, afterword mixed with biogas (fuel) and combusted in combustion chamber. Mechanical work is transformed to generator, exhaust gases power second power cycle. Fig. 4a presents the basic example of biogas Brayton system. To promote electricity generation an additional thermodynamic cycle with its own generator is installed. Heat of exhaust gases causes vaporization of working fluid, which onwards drives turbine. Principle of operation of second cycle is based on vapor Rankine thermodynamic transformations. Figure $4 \mathrm{~b}$ shows basic example of Rankine turbine. Model consists of evaporator, expander, condenser and pump.
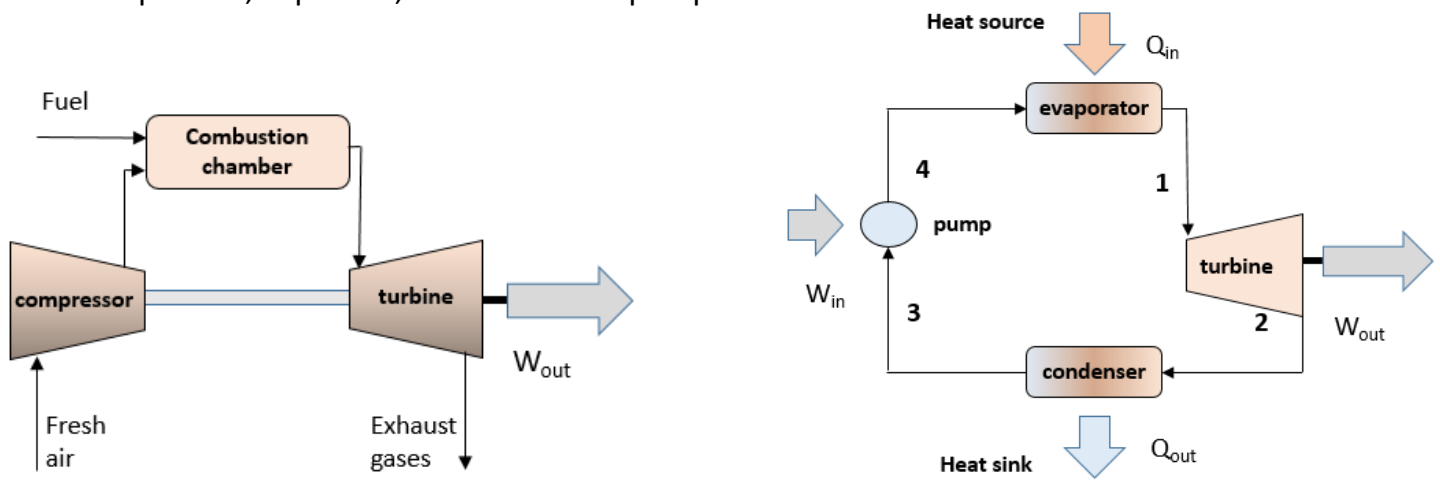

Fig. 4. Schematic of a) biogas turbine in Brayton open cycle b) vapor turbine in Rankine cycle Source: Authors'

To improve overall efficiency of the system authors propose second cycle with organic working fluid, which may be a mixture of hydrocarbons used in an ORC or an ammonia-water solution used in a Kalina cycle. In the ORC cycle organic low boiling temperature of such working fluid increases ability to transfer heat even from low temperature sources [24]. Kalina cycle bases on mixture of water and ammonia (each of which has a different boiling point) and after evaporator liquid and vapor phases are separated in the separator unit [25]. Basic ORC cycle is simple, on the other side Kalina cycle has better performance and change in the ammonia concentration allows to control by variating the concentration of ammonia [26]. Thus in the simulation Kalina cycle is used, various condensation of ammonia is analyzed in that non-conventional Rankine model.

\section{Simulative implementation}

Schematic of biogas combustion installation is presented below (Fig. 5). The model provides a combined-cycle process, that increases share of electricity production in total generation. Firstly biogas is mixed with ambient air compressed by compressor, which is driven by gas turbine connected to generator. Heat recovery vapor generator (HRVG) is a link between the gas turbine and organic cycle. Second cycle is based on Kalina cycle that consists of HRVG as evaporator, turbine with generator, condenser with absorber, pump, recuperator and ammonia separator. Last cycle contains cooling water that condensates organic fluid and which is next relieved outside the system. Table 3 presents the preset values of selected parameters.

Table 3. Values of parameters preset in simulation

\begin{tabular}{|l|l|l|}
\hline Temperature & Value & Apparatus \\
\hline Biogas flow influent & $0.15 \mathrm{~m}^{3} / \mathrm{s}$ & 4 \\
\hline Biogas LHV & $30.03 \mathrm{MJ} / \mathrm{kg}$ & 4 \\
\hline Combustor equilibrium temperature & $1100^{\circ} \mathrm{C}$ & 5 \\
\hline Isentropic efficiency of turbines & 0.8 & 6,10 \\
\hline Generators efficiency & 0.98 & 6,10 \\
\hline Temperature of water/ammonia leaving the HRVG & $80^{\circ} \mathrm{C}$ & 7 \\
\hline Content of ammonia in the cycle & Defined later & 14 \\
\hline Temperature of cooling water and ambient temperature & $15^{\circ} \mathrm{C}$ & 20 \\
\hline
\end{tabular}


According to calculation above the estimated gross potential of waste production in Dubrovnik is $24.27 \mathrm{GWh}$ which translates to $2.77 \mathrm{MW}$ of power transported with the fuel.

Gas turbine:

1. Air source

2. Air filter

3. Compressor

4. Combustor

5. Biogas source

6. Gas turbine + Generator

7. HRVG

8. Chimney

\section{Kalina cycle:}

7. Evaporator (HRVG)

10. Turbine + Generator

11. Absorber + Condenser

12. Pump

13. Recuperator

14. Separator

Cooling cycle:

11. Condenser

20. Source

21. Pump

22. Sink

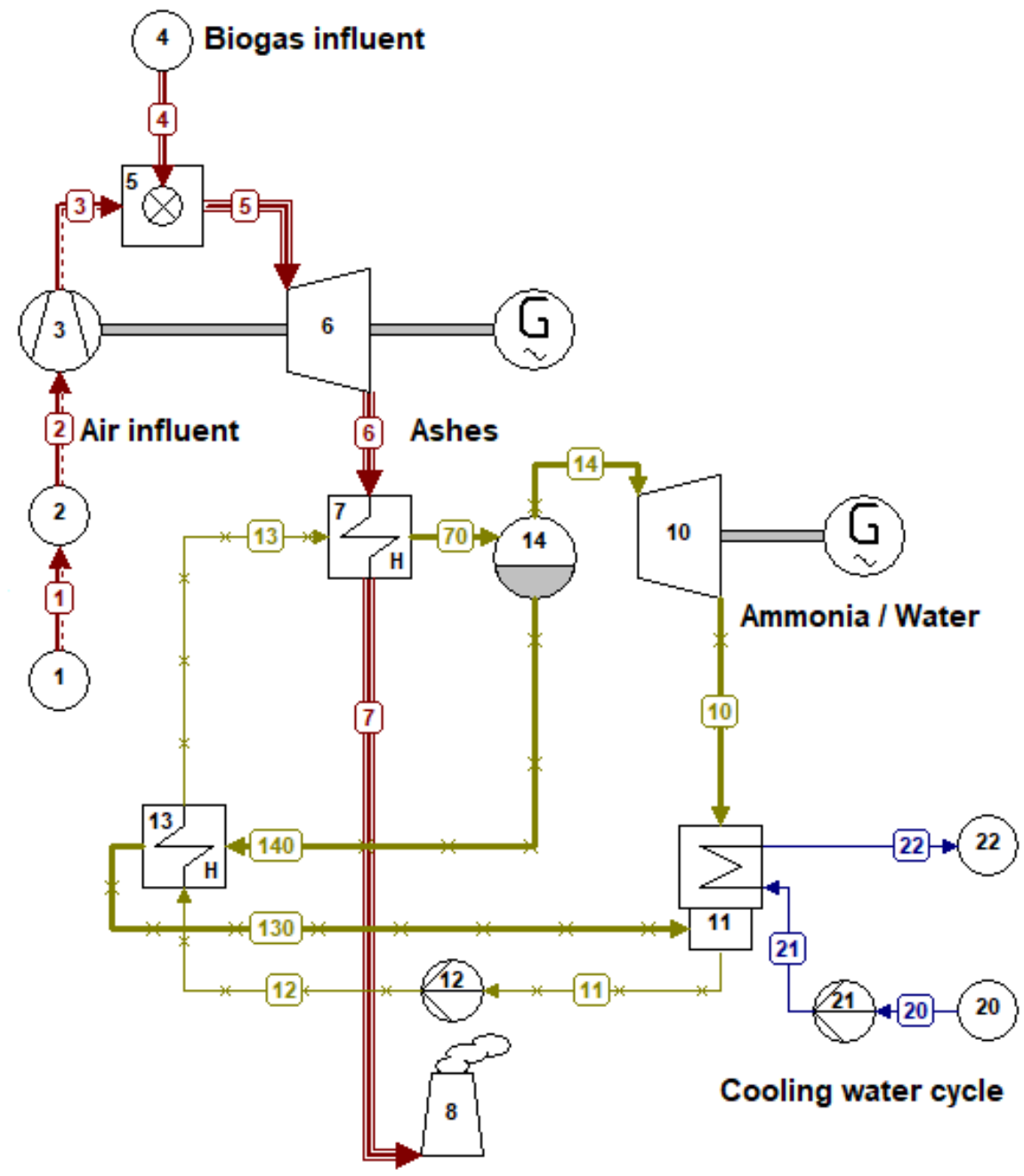

Fig. 5. Model of installation

Source: Authors' model of simulation in Cycle-Tempo

To detect the effectively best efficiency of the system the Kalina cycle was assumed with different amount of ammonia in working fluid. On the basis of Rama Usvika et al. [27] in this analysis authors propose mass content ammonia in working solution between $65 \%$ and $75 \%$.

Table 4. State of the model depending on the content of ammonia in Kalina cycle

\begin{tabular}{|l|l|l|l|l|}
\hline \multirow{2}{*}{ Cycle } & Parameter & \multicolumn{3}{l|}{ The content of ammonia in Kalina cycle } \\
\cline { 3 - 5 } & & $\mathbf{6 5 \%}$ & $\mathbf{7 0 \%}$ & $\mathbf{7 5 \%}$ \\
\hline \multirow{2}{*}{\begin{tabular}{l} 
Main $\begin{array}{l}\text { Brayton } \\
\text { cycle }\end{array}$ \\
\cline { 2 - 5 }
\end{tabular}} & Energy delivered with fuel [kW] & 2765.52 & 2765.52 & 2765.52 \\
\cline { 2 - 5 } $\begin{array}{l}\text { Kalina } \\
\text { cycle }\end{array}$ & Power recovered by generator 1 [kW] & 427.70 & 427.70 & 427.70 \\
\cline { 2 - 5 } & Power consumed by compressor [kW] & 1582.88 & 1582.88 & 1582.88 \\
\hline Cooling & Power consumed by pump 12 [kW] & 192.45 & 280.62 & 351.07 \\
\hline \multirow{2}{*}{ TOTAL } & Power consumed by pump 21 [kW] & 21.58 & 18.00 & 15.71 \\
\cline { 2 - 5 } & Gross efficiency [\%] & 88.01 & 84.96 & 82.53 \\
\cline { 2 - 5 } & Net efficiency [\%] & $\mathbf{2 2 . 4 2}$ & $\mathbf{2 5 . 6 1}$ & $\mathbf{2 8 . 1 6}$ \\
\hline
\end{tabular}

Source: Authors' 
The Table 4 presents the results of simulations. Achieved net efficiencies vary between $18.46 \%-25.61 \%$. Comparing the simulative results the higher content of ammonia the higher efficiency of the system. The simulative results point that mass flow through air turbine is constant. On the other hand along with increase of ammonia the mass flow in Kalina cycle is lower and less cooling water is expected.

For the analysis the most effective simulation is taken into consideration - with $75 \%$ of ammonia in Kalina cycle. Figure below contains Sankey diagram presenting the distribution of energy during the combustion (Fig. 6). The analysis of presented energy balance flow diagram points that the presence of second generator rapidly increases the electricity gain in the installation. Unfortunately, on the other hand Kalina cycle in installation increases the complexity of the system (additional pump uses part of available energy).

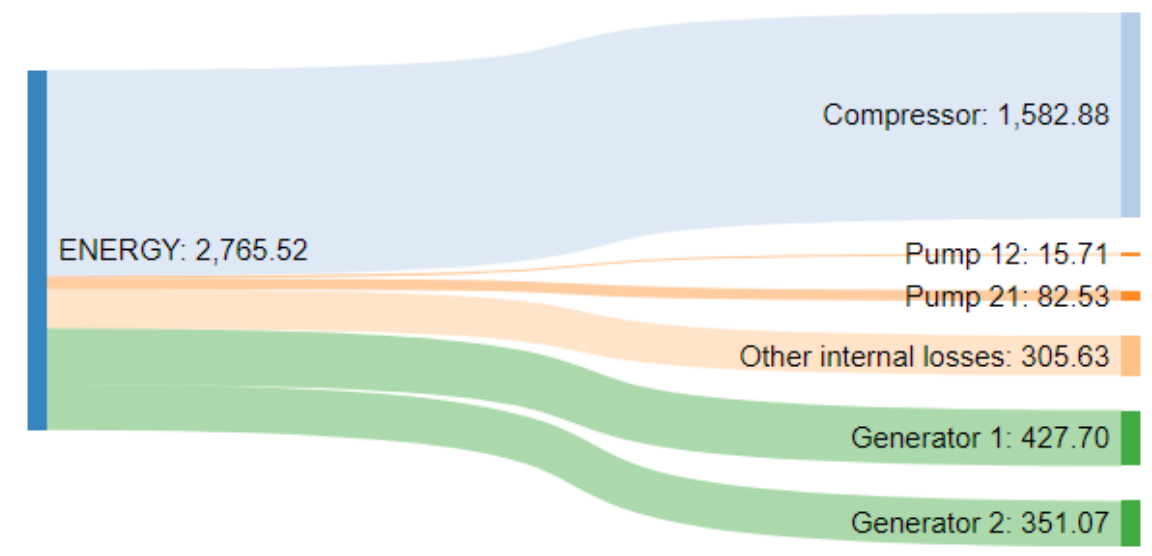

Fig. 6. Energy balance flow Sankey diagram for model with higher efficiency - with $75 \%$ of ammonia Source: Authors'

Sewage processing is energy consuming, so usable energetic yield with installation is reduced by waste preparation and exhaust gases purification. It is worth to add that, some other utilization techniques may be better for selected sorts of waste.

\section{Summary and conclusions}

In the touristic cities like Dubrovnik proper waste management is especially worth consideration. Assessments indicate the noticeable impact of tourism on the waste production. The proper environmental politic saves charm of city for both inhabitants and tourists. In the paper the energetic potential of waste produced in the touristic areas like Dubrovnik is considered.

Authors take sewage sludge and solid waste as potential source of electricity. Anaerobic digestion is utilizable way to extract biogas from waste matter. The biogas combustion is proposed to handle with the biogas produced in digesters. The schematic of two stage combined-cycle process fulfilling the expectations is reviewed. Paper introduces to gaseous cycle and Rankine based - ORC and Kalina cycles.

On the basis of available data the assessment of biogas potential is presented - exceeds 4 million $\mathrm{m}^{3}$ per year. Literature study presents that over $24 \mathrm{GWh}$ of biogas can be achieved. The simulation in Cycle-Tempo estimates the energetic potential of combined-cycle installation - in presented case $2.77 \mathrm{MW}$ of power transported with the fuel allows to generate $0.778 \mathrm{MW}$ of electricity. The calculated value translates to over $28 \%$ of energetic gross efficiency. It is worth to add that energetic yield must be reduced by the costs of waste processing necessary to prepare the biogas. On the other hand heat obtained during process might be used in anaerobic digestion tanks.

\section{Acknowledgements}

Data from "ESEIA Summer School 2017" in Dubrovnik prepared by Nikola Matak. 


\section{References}

[1] Croatian National Tourist Board, Tourism in Figures 2016, 2016.

[2] J. Kizielewicz, The Mediterranean Sea Region - the leader in the cruise ship tourism in Europe, vol. 36, no. 108 , pp. 80-88, 2013.

[3] Eurostat, Energy balance sheets, vol. 33, no. 9. 2016.

[4] Z. A. Velike and E. Sustave, 'New , Modern Hydro Power Plant Dubrovnik Control System', pp. 1-8, 2013.

[5] Rudine 34.2 MW Wind Power Plant, Croatia [Online]. Available: http://www.rpglobal.com/wind/croatia/rudine/ [Accessed: 17-Aug-2017].

[6] A. Falkoni and G. Krajacic, Linear correlation and regression between the meteorological data and the electricity demand of the Dubrovnik region in a short-term scale, Therm. Sci., vol. 20, no. 4, pp. 1073-1089, 2016.

[7] D. Schneider and B. Željko, Analysis of a sustainable system for energy recovery from municipal waste in Croatia, Manag. Environ. Qual. An Int. J., vol. 22, no. 1, pp. 105-120, 2011.

[8] M. Serdar, M. Serdar, M. Serdar, and M. Serdar, Use of sludge generated at WWTP in the production of cement mortal and concrete, J. Croat. Assoc. Civ. Eng., vol. 68, no. 03, pp. 199-210, 2016.

[9] D. Styles, H. Schönberger, and J. L. G. Martos, Best environmental management practice in the tourism sector. 2013.

[10] I. Kožić, Preliminary Report of Croatian Sustainable Tourism Observatory - Focal area: Adriatic Croatia, no. July, 2016.

[11] I. Gruber and D. Stead, Urban strategies for Waste Management in Tourist Cities, 2016.

[12] N. Matak, Ed., Data from 'ESEIA Summer School 2017' in Dubrovnik.

[13] K. Vatopoulos and D. Andrews, Study on the state of play of energy efficiency of heat and electricity production technologies. 2012.

[14] D. Elango, M. Pulikesi, P. Baskaralingam, V. Ramamurthi, and S. Sivanesan, Production of biogas from municipal solid waste with domestic sewage, J. Hazard. Mater., vol. 141, no. 1, pp. 301-304, 2007.

[15] I. Zsirai, Sewage Sludge as Renewable Energy, J. Residuals Sci. Technol., vol. 8, no. 4, pp. 165-179, 2011.

[16] M. Devine, Engines? Turbines? Both? Choosing Power for CHP Projects, no. August, 2013.

[17] L. Houdková, J. Boráň, J. Pěček, and P. Šumpela, Biogas - A renewable source of energy, Therm. Sci., vol. 12, no. 4, pp. 27-33, 2008.

[18] A. Matuszewska, M. Owczuk, A. Zamojska-Jaroszewicz, J. Jakubiak-Lasocka, J. Lasocki, and P. Orliński, Evaluation of the biological methane potential of various feedstock for the production of biogas to supply agricultural tractors, Energy Convers. Manag., vol. 125, no. October, pp. 309-319, 2016.

[19] S. A. Opatokun, V. Strezov, and T. Kan, Product based evaluation of pyrolysis of food waste and its digestate, Energy, vol. 92, pp. 349-354, 2015. 
[20] Y. Cao and A. Pawłowski, Sewage sludge-to-energy approaches based on anaerobic digestion and pyrolysis: Brief overview and energy efficiency assessment, Renew. Sustain. Energy Rev., vol. 16, no. 3, pp. 1657-1665, 2012.

[21] K. Tucki et al., Design of Digester Biogas Tank Part 1 : Biogas Calculator - Tool to Perform Biogas Energy Calculations, vol. 15, no. 1, pp. 75-82, 2015.

[22] Bioenergy in Germany : Facts and Figures Solid fuels Biofuels, Bioenergy Ger. Facts Fig., no. January, 2012.

[23] Y. Demirel, Energy: Production, Conversion, Storage, Conservation, and Coupling, vol. 69. 2012.

[24] E. Macchi, Organic Rankine Cycle (ORC) Power Systems Technologies and Applications, 2016.

[25] M. Yari, A. S. Mehr, V. Zare, S. M. S. Mahmoudi, and M. A. Rosen, Exergoeconomic comparison of TLC (trilateral Rankine cycle), ORC (organic Rankine cycle) and Kalina cycle using a low grade heat source, Energy, vol. 83, pp. 712-722, 2015.

[26] J. Milewski and J. Krasucki, Comparison of ORC and Kalina cycles for waste heat recovery in the steel industry, vol. 97, no. 4, pp. 302-307, 2017.

[27] R. Usvika, M. Rifaldi, and A. Noor, Energy and exergy analysis of kalina cycle system ( KCS ) 34 with mass fraction ammonia-water mixture variation, vol. 23, pp. 1871-1876, 2009. 